\title{
Immune Problems in Central Nervous System Cell Therapy
}

\author{
Roger A. Barker* and Håkan Widner ${ }^{\dagger}$ \\ *Cambridge Center for Brain Repair and Department of Neurology, Cambridge CB2 6SP, United Kingdom; ${ }^{\dagger}$ Department of \\ Clinical Neurosciences, Division of Neurology, Lund University Hospital, S-221 85 Lund, Sweden; and Department of \\ Physiology and Neuroscience, Wallenberg Neuroscience Center, Lund University, 22100 Lund, Sweden
}

\begin{abstract}
Summary: Transplantation of cells and tissues to the mammalian brain and CNS has revived the interest in the immunological status of brain and its response to grafted tissue. The previously held view that the brain was an absolute "immunologically privileged site" allowing indefinite survival without rejection of grafts of cells has proven to be wrong. Thus, the brain should be regarded as a site where immune responses can occur, albeit in a modified form, and under certain circumstances these are as vigorous as those seen in other peripheral sites. Clinical cell transplant trials have now been performed in Parkinson's disease, Huntington's disease, demyelinating diseases, retinal disorders, stroke, epilepsy, and even deafness, and normally are designed as cell replacement strategies, although implantation of genetically modified cells for supplementation
\end{abstract}

of growth factors has also been tried. In addition, some disorders of the CNS for which cell therapies are being considered have an immunological basis, such as multiple sclerosis, which further complicates the situation. Embryonic neural tissue allografted into the CNS of animals and patients with neurodegenerative conditions survives, makes and receives synapses, and ameliorates behavioral deficits. The use of aborted human tissue is logistically and ethically complicated, which has lead to the search for alternative sources of cells, including xenogeneic tissue, genetically modified cells, and stem cells, all of which can and will induce some level of immune reaction. We review some of the immunological factors involved in transplantation of cells to CNS. Key Words: Immunity, brain, transplantation, embryonic tissue, gene therapy, xenograft.

\section{THE BRAIN AS A TRANSPLANTATION SITE}

In 1953, the term "immunologically privileged site" was coined, denoting a prolonged graft survival in comparison with another, nonprivileged site $^{1}$ and the brain was recognized as being one such privileged site among others. ${ }^{2}$ The mechanisms underlying this privilege are several fold and results from the blood-brain barrier (BBB), the absence of professional antigen-presenting cells (APCs) and the sparse lymphatic drainage from the CNS. These factors were then thought to be important in producing a variety of possible immunological phenomena such as "ignorance" (i.e., absence of activation of the immune system because it is unaware of any foreign tissue being introduced); "deviance" (the immune responses are deflected from the target); or "acceptance," "partial tolerance" or "in situ tolerance," all of which refer to the incomplete capacity of the immune system to reject tissue based on local factors that affect the immune response. ${ }^{3}$ However, it is now clear that the CNS does

Address correspondence and reprint requests to Håkan Widner, Department of Clinical Neurosciences, Division of Neurology, Lund University Hospital, S-22185 Lund, Sweden. E-mail: hakan.widner@neurol.lu.se. not display absolute immunological privilege as activated lymphocytes can cross the BBB, certain cells such as microglia may have an APC capacity and there is lymphatic drainage from the CNS into the deep cervical lymph nodes. In addition, in the context of neural grafting, there will be inevitable damage to the BBB. The privileged status of the brain is now regarded as the result of a balance of regulated events that produces either immune privilege or effective responses. ${ }^{4,5}$ In terms of neural grafting, there are several factors that contribute to the timing and intensity of the rejection response and this includes the type of graft transplanted, the degree of immunological disparity between donor and recipient, and how and where the tissue is implanted.

Immunological disparity reflects the differences between host and donor expression of immunogenic epitopes, ${ }^{6}$ and can be major or minor in their contribution to the immune rejection responses. Minor transplantation antigens are endogenous polymorphic peptides (sometimes tissue-specific), which are processed and presented within the variable portions of major histocompatibility complex (MHC) I or II molecules. Lipids and carbohydrates are presented, but in this case, with the invariant 
CD1 molecule. ${ }^{7}$ Major antigens, e.g., the MHC I and II, the $\mathrm{ABO}$ system or galactose $\alpha 1,3$ galactose in porcine tissue, can be associated with the presence of naturally occurring antibodies, which will produce a very strong humoral rejection response with complement activation. Thus, the rejection process has both a cellular and humoral component, although the contribution of each is directly related to the phylogenetic distance between donor and host. $^{8,9}$

When cells, tissue, or organs are grafted between relatively closely related species, concordant xenografts, the immune reactions are dominated by cellular reactions against xenogeneic MHC/xenogeneic peptides, and resemble allograft responses. The key cellular mediators of graft rejection being the $\mathrm{T}$ lymphocytes $\left(\mathrm{CD} 4^{+}\right.$and $\mathrm{CD}^{+}$) and microglial cells. ${ }^{10}$

In more distantly related species, discordant xenografts, the immune responses typically involve the innate responses such as the complement system, natural killer (NK) and NKT cells, natural antibodies, and the coagulation cascade systems. ${ }^{11}$ So, for example, with a vascularized whole organ xenograft, there is an antibody and complement-dependent hyper-acute rejection. The reason for this being that humans and nonhuman primates have a deletional mutation for the $\alpha-1,3$ galactosyl transferase $(\alpha-1,3-\mathrm{Gal})$ enzyme, and so do not express the Gal- $\alpha-1,3-$ Gal polysaccharide epitopes on lipids and proteins. This epitope is, however, expressed on bacteria in the normal gut flora, and thus all humans have high titers of anti-Gal "natural antibodies,"12 which will be activated once xenogeneic tissue expressing this epitope is placed in the human host.

Thus, the immune response to grafted tissue is complex, but is dependent on a number of variables, which include the phylogenic relationship of donor tissue to host and its composition and mode of implantation.

\section{THE ROLE OF TISSUE PREPARATION, SITE, AND MODE OF IMPLANTATION IN GRAFT REJECTION}

In addition to the immunological differences, the type of graft being used is important, as well as how the cells, tissue, or organs are being implanted. Cellular grafts (as oppose to tissue pieces) to the brain are secondarily vascularized, either with host endothelial cells growing into the graft, or with intact microvessels forming connections with the host vasculature. Suspension neural grafts are revascularized mainly by host vessels and after implantation into the parenchyma, and a blood-brain barrier for macromolecules is reformed within $\sim 1$ week. ${ }^{13,14}$ In contrast, a non-neural tissue graft, such as skin, does not form a blood-brain barrier. ${ }^{15}$ Grafts of solid pieces of tissue with intact microvessels forming connections with the host vasculature fare worse than suspension grafts.

In addition to the actual type of transplant being grafted, the site within the brain matters, with very poor graft survival of incompatible tissue in areas close to the ventricular system (e.g., hippocampus) whereas in the parenchyma (e.g., putamen) graft survival is more readily obtained.

\section{ANTIGEN-PRESENTING CELLS OF THE CNS: WHAT AND WHERE ARE THEY?}

The view as to which cells within the brain are responsible for the antigen presentation (APC) from the brain has been revised. The previously held notion that the brain lacked not only lymphatic vessels but also efficient antigen-presenting cells, such as the dendritic cells $(\mathrm{DCs})^{16,17}$ has been replaced by a view of a dynamic interplay between cells within the brain parenchyma.

There are two populations of bone marrow-derived microglia cells: one resting, permanent type scattered throughout the parenchyma, which enters the brain during the fetal period, ${ }^{18}$ and another that is periodically exchanged in the perivascular spaces. ${ }^{19,20}$ The resident microglia cells are considered to be relatively immature, although they can mature into macrophages and DCs, the most efficient of all antigen-presenting cell types. ${ }^{21,22}$ So, for example, in isolated slice cultures, devoid of any systemic circulation, parenchymal microglia can migrate to the vascular space and form round, macrophage-like cells in response to injury. ${ }^{23}$

The perivascular spaces are probably more important for presentation of intracerebral antigens in humans and so the perivascular microglia cells (pericyte), which are specialized bone marrow-derived cells that have APC function ${ }^{5}$ are probably critically important in graft rejection within the CNS. These perivascular spaces can be organized into lymphoid tissue as may be seen in chronic immune-mediated disorders such as multiple sclerosis. ${ }^{24}$ Furthermore, local paracrine effects of certain cytokines and growth factors, such as astrocyte-derived granulocytemacrophage colony stimulating factor and macrophage colony stimulating factor, may also contribute to the maturation of immature microglia cells into DCs and fully effective APCs. ${ }^{25}$

The strongest stimulus for an allogeneic transplantation response is donor-derived APCs. The number of these donor-derived APCs and their drainage route determines mainly how efficient the recipient is immunized against the graft tissue. Allogeneic APCs can directly activate host lymphocytes, so-called direct presentation process. Alternatively, host (as opposed to donor) APCs can also take up donor antigens, either in the form of intact MHC molecules or allogeneic or xenogeneic fragments of proteins, and present these in the context of host 


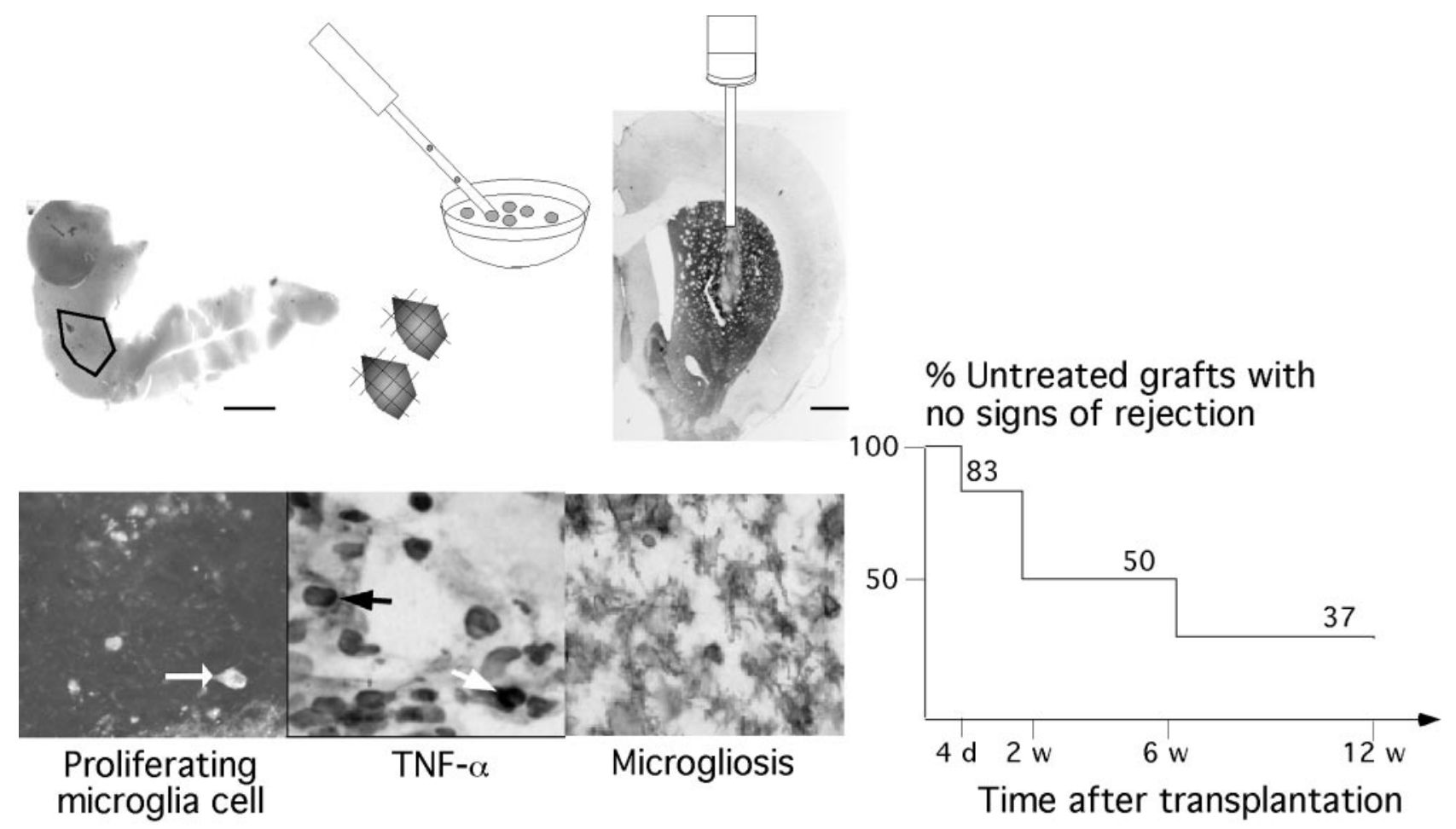

FIG. 1

MHC, as an indirect presentation process. ${ }^{26}$ As to which of these routes of antigen presentation is dominant in neural grafts is not known, although the evidence to date would support the indirect over the direct route.

\section{ACTIVATION OF THE IMMUNE SYSTEM: WHAT IS NEEDED?}

In the lymphoid tissue, the conditions for activation of specific lymphocytes are optimized. When the T-cell receptor binds with a MHC/antigenic peptide complex, in conjunction with a re-enforcing signal from the CD4 CD8 molecules, and additional costimulatory ligands form complexes, such as B7-CTLA4, CD40-CD40L, LFA3-CD2, ICAM-1-LFA1, B7-CD28, activation of the $\mathrm{T}$-cell takes place. If this sequence is not fulfilled, and no costimulatory activation signal is provided, this can lead to anergy of the T cells. ${ }^{27}$ This anergy can be regarded as a partial tolerance. Alternatively, to block costimulation may lead to the formation of regulatory $\mathrm{T}$ cells that modify the host responses, ${ }^{28}$ which will remove or dramatically reduce the host response to the tissue expressing that antigen.

In general immunosuppressive drugs used in transplantation interfere with the activation of $\mathrm{T}$ cells and to some extent the proliferation of $\mathrm{T}$ and $\mathrm{B}$ cells, whereas most immunomodulatory interventions interfere with the costimulatory functions.

\section{BARRIER SYSTEMS WITHIN THE CNS TO IMMUNE RESPONSES}

The brain is ensheathed by a series of barriers, effectively isolating brain metabolism and electric activity. The meningeal-brain barrier complex, the brain-choroidal plexus, the pial vessel-extracellular space, and the capillary blood-brain barrier are each components of this insulation of the brain.

The capillary barrier consists of high-resistance tight junctions between the endothelial cells, which means that cells normally have a very restricted passage. In addition, this barrier has a low pinocytotic capacity, a high electrostatic potential difference across the lumen excluding charged substances, along with several enzymes degrading a vast number of substances rather than allowing passage, and a low response to substances that normally increase the passage of fluid across the endothelium, such as histamine and bradykinin. There are also three complexes of active transporters such as multidrug resistance protein, breast cancer resistance protein, and P-glycoproteins, ${ }^{29}$ which actively exclude substances and drugs. Furthermore, immunoglobulins, complement factors, and other plasma factors are usually present in the brain parenchyma at concentrations that are one twohundredth or less than that found in plasma.

In response to a transplant, lymphocytes are activated, proliferate, and then enter the blood circulation. These cells then "home" to the graft, directed by cues present 
on the endothelium of the vessels in and around the graft. The brain endothelium is no exception, and can express a number of these homing signals, under the control of transcription factors that respond to inflammatory stimulus. Proinflammatory cytokines such as tumor necrosis factor- $\alpha, \gamma$-interferon, interleukin-1 (IL-1), and nitric oxide induce expression of intercellular cell adhesion molecule-1 (ICAM-1) and vascular cell adhesion molecule-1, the latter being crucial for the entry of cells to the CNS. ${ }^{30,31}$ Once across the BBB, further migration may be mediated by chemokines such as IL- 8 , inducible protein-10, RANTES, macrophage inflammatory protein-1, and monocyte chemoattractant protein- $1 .{ }^{31}$ In addition, activated lymphocytes can also express surface membrane-bound enzymes capable of degrading the endothelial glycocalyx facilitating the passage of such cells.

\section{LOCAL IMMUNOSUPPRESSIVE FACTORS WITHIN THE CNS}

It has been suggested that the brain and related tissue, such as the eye, contain locally immunosuppressive factors $^{2,32}$ and this includes TGF- $\beta$ and related cytokines which as a family act locally as anti-inflammatory, antimitotic, downregulatory cytokines, with TGF- $\beta$ itself being the endogenous ligand for the immunophilins. ${ }^{33}$ In addition, the internal milieu of the brain has been suggested to favor tolerance development or anergia, although the conditions may change after local trauma and inflammation. ${ }^{3}$ Factors that have been implicated in this latter process are inducible FAS/FAS-L expression in the brain after trauma, ${ }^{34}$ leading to the induction of cell death of invading lymphocytes. Other factors produced locally or by invading subsets of lymphocytes may also contribute to the formation of regulatory cells, although the identity of these factors is currently not known.

\section{IMMUNOSUPPRESSIVE DRUGS AND THEIR ROLE IN NEURAL GRAFTING}

There are numerous immunosuppressive drugs and protocols designed for particular whole organ allografting paradigms, such as renal and lung transplants. The most effective protocols with the least side effects are constantly being evaluated, and at the present time there is no consensus as to the optimal immunosuppressive regime (if any) for neural transplantation.

When immunosuppression has been used, the motives have been to ensure the best survival chances of the grafted, often compromised neurons, without the additional burden of an immune reaction. Even if the brain has a degree of immunological privilege, the use of immunosuppression will aid in the survival by safe-guarding against any activation of the immune system that may occur, and also ensures that when the inflammatory reactions have subsided, the graft is no longer able to activate the immune system.

The most extensive immunosuppressive protocol employed in clinical trials to date has been that used in patients in the Swedish Parkinson's disease neural transplant program. These patients have all received triple drug therapy involving cyclosporin A (starting at a dose of $3-5 \mathrm{mg} / \mathrm{kg} 2$ days before implantation, aiming for a serum concentration of $200-250 \mathrm{ng} / \mathrm{ml}$ at time of surgery, and a maintenance level of $\sim 100-150 \mathrm{ng} / \mathrm{ml}$ ), 2 $\mathrm{mg} / \mathrm{kg}$ azathioprine, and an intravenous dose of $500 \mathrm{mg}$ methylprednisolone at the time of implantation, followed by oral $100 \mathrm{mg}$ of prednisolone, reduced to a maintenance dose of $10 \mathrm{mg}$ per day after 2-3 months. The treatment is then maintained for the entire period between grafting sessions (i.e., time to graft both sides of brain) and for 12 months after the final implantation, with a slow tapering over several months after that. ${ }^{35}$ Using this regime, no overt rejection episodes have been observed, nor any deterioration after cessation of the treatment. There has been only one serious, but well recognized, side effect linked to the treatment, a skin cancer that was readily contained and excised surgically. ${ }^{35}$ These three drugs have proved not to be detrimental to the development of the embryonic primary cells ${ }^{36}$ and indeed at higher concentrations than can be achieved in vivo. Indeed, immunophilins, cyclosporin A, and tacrolimus (FK506) have all been shown to actually protect embryonic neural tissue against the metabolic insult during the preparation phase. Furthermore, the recent evidence that PD may have an inflammatory component to its pathogenesis, ${ }^{37}$ further suggests that the use of these drugs is to be recommended in the context of neural grafts. Additional drugs, which are routinely used clinically in peripheral organ allograft programs, include mycophenylate mophetil (which targets lymphocytes, especially B cells) and sirolimus, with a unique and different mode of action to that of tacrolimus and cyclosporin A. However, neither of these agents have been used in neural grafting. Immunomodulators, such as anti-IL-2 and anti-IL-2 receptors (anti CD25) are also in routine use as induction therapy with peripherally placed transplants and a large number of other immunomodulators aimed at blocking costimulation used alone or in combination have been considered but so far their clinical use has been limited.

In neural transplantation, immunomodulators have been used experimentally, in particular with xenografts. Antibodies against T-cell receptor anti-TCR $\alpha \beta$ and T cells have been used to enhance the survival of intracerebral neural xenografts in rats. ${ }^{38,39}$ Larsson and colleagues ${ }^{40,41}$ have also explored the use of blockers to T-cell costimulatory molecules as an alternative route to tolerance, therefore highlighting the value of targeting this arm of the immune response for xenograft survival. 
However, the future use of such immunomodulators for clinical purposes needs to be systematically addressed.

\section{THE ROLE OF IMMUNOSUPPRESSION AND NEURAL ALLOGRAFTS: THE EXPERIMENTAL DATA}

In animal experiments, rejection of allografts may be observed, but also prolonged graft survival is possible in spite of complete MHC incompatibility. ${ }^{8,42}$ Favorable graft survival occurs in particular if suspension grafts are implanted stereotaxically with an atraumatic technique into the parenchyma away from the ventricular system. Despite long-term graft survival without any immunosuppression, there is evidence for host immunization. ${ }^{43}$ When repeated intracerebral allografts are made with a long interval separating them, the first established graft is not affected by the latter graft, nor is the second graft necessarily rejected, but there is evidence for increase host responses around the grafts. ${ }^{44}$ This indicates that the immunization is relatively weak but exists, and that the effector systems are regulated. In strongly preimmunized animals, the subsequent brain tissue grafts are promptly rejected. If an established graft is challenged with a strong stimulus (skin graft) late after the first implantation, it may not be rejected, although a slow, chronic rejection may be observed. However, if this skin graft challenge occurs early after the first graft, prompt rejection is the rule. ${ }^{45}$

Of interest, transplantation to a site where microglia and astrocytes have been already been activated (e.g., by a toxin to produce an inflammation) resulted in better allograft survival. This is probably a result of the production of growth factors in the area. ${ }^{46}$ If rejection does occur in the brain, there may be "innocent bystander" damage, which has been experimentally tested in one study with mixed allogeneic and xenogeneic grafts. In the group with rejection of the xenograft, there was a reduced syngeneic or allogeneic graft survival, compared with immunosuppressed controls without any signs of xenograft rejections. ${ }^{47}$

There are few studies on the effects and need for immunosuppression in allogeneic neural grafts. Wood et al. ${ }^{48}$ used anti-CD25 antisera with increased survival of grafted tissue in the ventricular system, and azathioprine, prednisolone, and cyclosporin A have all proved to be nontoxic to embryonic neural tissue.

\section{CLINICAL ALLOGENEIC NEURAL TISSUE TRANSPLANTATION AND IMMUNOSUPPRESSION}

Grafting of allogeneic embryonic neural tissue into the CNS of animals has now reached the level of clinical trials with Parkinson's disease (PD) and recently also Huntington's disease (HD). ${ }^{49,50}$

Embryonic allogeneic neural tissue grafts have been performed in more than 350 patients with PD and this procedure has been shown to be effective in ameliorating many of the symptoms in PD. In the best cases, patients have been able to return to full-time employment, and they have been able to withdraw all anti-parkinsonism and immunosuppressive drug treatment. There is now proof-of-principle regarding the possibilities to repair the brain with embryonic primary neural tissue with restoration of neuronal circuitries. ${ }^{51-54}$ However, the technique is far from being standardized and several studies have failed to reach the same results.

Multiple donors are needed to achieve sufficient graft effects. This has been directly tested in the Tampa study, ${ }^{53}$ where better effects were generally obtained with multiple donors. The implication from the immunological point of view is that there is a greater likelihood that antigens are reintroduced if sequential grafts with multiple donors are performed, with a greater demand for immunosuppression, although embryonic brain tissue expresses few such antigens.

The embryonic donor tissue can be stored using special hibernation media for up to 10 days, with cryopreservation proving less successful. ${ }^{55,56}$ The effects of hibernation on the antigenicity of the tissue is not known, although short-term culture may reduce the number of donor APCs, but at the cost of a lower survival rate of the dopaminergic neurons. This may have been observed in the Freed study, ${ }^{54}$ in which tissue was cultured before implantation for up to 4 weeks. There was poorer survival than expected with other preparation methods, although in this study none of the patients were immunosuppressed, which may be relevant. ${ }^{52,57,58}$

The majority of patients entered into clinical neural allograft trials have been on immunosuppressive treatment for $\sim 18$ months with some continuing on therapy for up to 5 years. In all cases, withdrawal has not resulted in any rejection episodes. However, T cells have been observed in the site of the graft after cessation of cyclosporin A in a case that came to autopsy 12 months after immunosuppression was stopped, and 18 months after grafting, although the graft had survived well with marked clinical benefit to the patient. ${ }^{58,59}$ This indicates that chronic rejection events may take place, or that regulatory mechanisms within the brain may also be operative. These chronic inflammatory reactions may theoretically play a role in the recently reported development of abnormal movements (dystonia and dyskinesias) seen in the double-blind U.S. transplant trials. ${ }^{53,54} \mathrm{It}$ is possible to speculate that a chronic immune response, or activated microglia cells, produce factors, cytokines, and growth factors that affect the function and graft 
structure. Experimental studies are underway to address this in animal models.

Positron emission tomography (PET) can directly visualize the presynaptic dopamine transporters and the dopa-decarboxylase capacity, as an objective measurement of dopamine production, and this seems to correlate directly with clinical effects. Tracers specific for inflammatory responses, particularly microglia, PK11195 can be used to detect activated microglia around the grafts, but has so far not been used for a systematic study. Occasional patients in Swedish/UK studies have been scanned before and after withdrawal of the immunosuppression without signs of increased activity afterward (our unpublished data).

\section{XENOGENEIC NEURAL GRAFTS}

There are major obvious practical and ethical problems with the use of aborted human tissue in clinical programs of transplantation that prevent its widespread adoption. ${ }^{9,60}$ This has led to the search for alternative sources of cells, including other species, such as the pig. ${ }^{10}$

There are $\sim 200,000$ dopaminergic neuroblasts in the pig, and the optimal age for harvesting these cells appears to be embryonic day 26-27. If cells are taken at this age and xenografted into the adult CNS, they are rejected. The immune responses induced against this discordant embryonic porcine tissue has been addressed in mice and rats, and the critical factors for graft rejection have been determined. ${ }^{10}$ It is clear from studies in rats that xenogeneic grafts are rapidly rejected over a period of days to weeks through a combination of cellular and humoral immune processes. It is also clear that antibodies and components of the complement cascade probably also play a role. ${ }^{61,62}$ However, in nude athymic rats, neural xenografts survive indefinitely. ${ }^{63}$ Furthermore, in vitro studies ${ }^{64}$ have demonstrated that human T-cell $\left(\mathrm{CD}^{+}\right.$and $\left.\mathrm{CD} 8^{+}\right)$proliferation is induced by porcine embryonic tissue and that pretreatment of the porcine tissue with human serum reduced the proliferative response of human $\mathrm{T}$ cells. This suggests that such an approach might be useful clinically to improve graft survival, possibly by removing the more immunogenic cells. Conventional immunosuppressive drugs used as monotherapy (e.g., cyclosporin A or tacrolimus) do not protect grafts effectively, ${ }^{65-67}$ but this can be improved if combined with other drugs such as prednisolone. ${ }^{65}$ Short courses of treatment with molecules that block T-cell costimulation [CD40L, LFA1, and CTLA4 $\operatorname{Ig}(40,41)$ ] have resulted in very good graft survival in mice, although long-term studies are needed to determine whether this therapy could be used clinically. ${ }^{41}$

The role for humoral factors in xenograft rejection has been addressed using a number of different approaches.
In immunoglobulin-deficient recipient mice, ${ }^{62}$ embryonic porcine ventral mesencephalic (VM) cells survived better than in control mice, demonstrating that antibodydirected complement-mediated rejection of xenografts was important. Furthermore, porcine xenografts undergoing rejection are infiltrated with $\mathrm{CD}^{+}$cells and stain positive for IgM and complement component (C3) deposition, ${ }^{61}$ and transient depletion of complement (using cobra venom factor) can prolong graft survival, although it does not prevent rejection.

Humans have preformed, natural anti-pig antibodies that target the $\alpha-1,3-G a l$ epitope and so human sera has a cytotoxic effect on porcine embryonic VM cells in the presence of complement. In addition to the known antigens, there are three non- $\alpha-1,3-$ Gal epitopes on embryonic porcine dopaminergic cells reactive with IgM present in the human serum. ${ }^{68}$

Transgenic porcine VM tissue, expressing either the human complement inhibitor CD59 or human $\alpha$-1,2-fucosyltransferase in combination with a recipient treatment with anti-C5 antibodies (H transferase), survives up to 12 weeks in parkinsonian primates. ${ }^{69}$ However, the level of expression of these human complement regulatory proteins is generally low in transgenic embryonic pig brain. ${ }^{70}$

An alternative mode of interfering with the rejection process provoked by porcine neural tissue is to block MHC class I molecules in the donor tissue by immunomasking with $\mathrm{F}(\mathrm{ab})^{2}$ antibody fragments, although the level of expression of this epitope is very low in embryonic porcine neural tissue. Fetal neural porcine tissue, pretreated with the $\mathrm{F}(\mathrm{ab})^{2}$ antibody fragments against porcine MHC I (SLA I) before implantation to the striatum, enhanced graft survival compared with the untreated group. ${ }^{9}$

\section{CLINICAL TRIALS USING EMBRYONIC PORCINE TISSUE}

The first clinical trial with pig tissue was conducted in the U.S. as a phase I study, comparing two regiments of immunosuppression, $5 \mathrm{mg} / \mathrm{kg}$ cyclosporin $\mathrm{A}$ as monotherapy versus immunomasking of anti-SLA I antigens. Six patients each were grafted and followed for 12 months. There was no improvement in the group data, but two patients are reported to have $15 \%$ improvement in clinical rating scales. ${ }^{71}$ One case came to autopsy 7 months after grafting and histologically pig tissue was detected, but only 638 dopaminergic cells were seen, far short of the 80,000-100,000 cells needed for clinical effects. ${ }^{72}$ Despite the use of immunosuppression with cyclosporin A, lymphocyte infiltration was also seen in the graft region. This extremely low survival rate correlates with a low ${ }^{18} \mathrm{~F}$-dopa PET signal.

Nevertheless, a second multicenter phase II study has 
been performed in the U.S., with sham-operated control patients. Ten patients were grafted, and eight were randomized as controls and underwent sham surgery and sham immunosuppression. PET images may have indicated hot spots in certain areas, and clinical evaluations at 18-month follow-up showed that both groups had a similar modest (20-25\% on Unified Parkinson's Disease Rating Scale) improvement, except for a reduction time spent with dyskinesias. The reason for this improvement in all patients (control and grafted) is not known.

In addition, 12 patients with HD have been grafted with embryonic neural pig tissue. ${ }^{73}$ The functional effects have been negative.

However, all of these clinical trials must be seen to be premature given the current experimental data that exists in the laboratory using porcine xenografts.

\section{XENOGRAFT AND ZOONOSES}

Animal endogenous retroviruses [e.g., porcine endogenous retrovirus (PERV)] are proviral DNA sequences integrated into the host genome, with pig chromosomes harboring at least 50 copies of PERV. ${ }^{74}$ There has been no report of any human becoming infected with PERV after exposure to porcine tissue. A retrospective study of 160 patients treated with living pig tissue up to 12 years previously concluded there was no evidence for persistent PERV infection in any of the patients. ${ }^{75}$ In the human neural xenograft recipients there have been no complications in terms of host infections, nor any demonstration of anti-PERV antibodies, and negative PCRs for PERV. ${ }^{76}$

Thus, it would appear that although there are theoretical risks of PERV infection in patients grafted with porcine neural tissue, this is yet to be seen as a major issue in any studies using this tissue.

\section{GENETICALLY MODIFIED TISSUE}

Non-neuronal cells cannot be used for a repair strategy that requires reformation of neuronal circuitries and a controlled synaptic release of transmitter; however, attempts to replace neurotransmitters with transfected cells functioning as "minipumps" have been considered, but tend to resulting in incomplete behavioral recovery. ${ }^{77,78}$

In neurodegenerative disorders, a lack of adequate growth supporting substances has been suggested to contribute to the degenerative process and therapeutic approaches to supplement these essential growth factors have been suggested in a number of conditions, provided the correct growth/trophic factor can be identified.

The delivery of these substances by the implantation of a genetically modified cell or via direct gene transfer is thus a more appropriate approach.
However, there are several examples in which the use of such grafts results in rejection even when the cells have been syngeneic or allogenic. Thus, transfection itself seems to alter the immunogenicity of the tissue such that rejection occurs and so there is a need for continuous immunosuppression. ${ }^{79-81}$ Indeed, even if transcriptiondefective virus vectors have been used, it is clear that intracellular antigens find their way to the surface with MHC, or antigen can be picked up by host APCs and an effective immune response can be mounted.

Encapsulation of transfected xenogeneic cell lines has also been suggested as a way to avoid immune responses, although there are several examples of a noncellular response against such encapsulated cells resulting in graft destruction. ${ }^{82}$

\section{STEM CELLS}

Stem cells involve a novel, largely unknown biological principle of controlled in vitro differentiation to replace lost cells. There are several different types of cells of various origin and developmental phases, as reviewed in Temple. ${ }^{83}$ The most immature and potentially most useful are embryonic stem (ES) cells, although there are natural anxieties that these cells will result in teratomas or other uncontrolled cell growth. There are also hopes that therapeutic cloning of ES cells with the recipient nucleus will result in a cell type that is more or less devoid of immunogenicity. ${ }^{84}$ In a concordant xenograft experiment, a number of intrastriatal, low-density, transplants of mouse ES cells developed some dopamine neurons, although rejection was also seen, despite ongoing chronic immunosuppression; in addition, $22 \%$ of the rat recipients developed fatal intracerebral teratomas.

In contrast to ES cells, a recent in vivo study by Armstrong et al. ${ }^{86}$ provided evidence that xenografted embryonic porcine expanded neural precursor cells (ENPs) may be an even more flexible source of cells for use in neural transplant therapies in which circuit reconstruction is required. Taking advantage of both the enhanced axonal outgrowth, thought to be characteristic of xenografted neural tissue, and the plastic nature of multipotential neural stem cells, this study examined the ability of porcine ENPs to differentiate into projection neurons and thereby reconstruct degenerate neural circuitry in the cyclosporin A-immunosuppressed 6-OHDA-lesioned rat model of PD. As an alternative to embryonic neural stem cells or ES cells, the use of adult progenitors, taken from the patients themselves, may be a more useful approach at least from an immunological perspective. Such an approach does presuppose that the progenitors are not affected by a disease process itself. At the present time, this approach still remains in its infancy.

Migration is a well documented characteristic of 
ENPs $^{87,88}$ but has not been as extensively studied in primary neural graft-derived cells. Most studies examining cell migration from primary neural grafts have been in neonatal hosts. ${ }^{89}$ An inability to respond to speciesspecific inhibitory cues may allow greater migration of xenografted cells than equivalent allografted cells, and therefore enhance integration of grafted neurons with host circuitry and enable migration of cells to sites of pathology well outside the graft mass itself. If this proved to be the case, then there may be a primary advantage in using xenogenic tissue.

Another factor or concern when it comes to stem cells is the effect of the local inflammatory response on their development as well as the effects of immunosuppressive drugs. This is exemplified by the temperature-sensitive cell line RN33B, which, when grafted into the subretinal space of rats, develops in part into retinal neurons. Immunosuppression with cyclosporin $\mathrm{A}$ is needed in spite of the cell being allogeneic, because when grafted without treatment, non-neuronal development occurred. Furthermore, when the rats were grafted using the same process but the hosts were immunosuppressed with tacrolimus, massive gliosis developed with no retinal cells. ${ }^{90,91}$ Overall, the immunology of grafted stem cells has not been extensively studied in depth, ${ }^{92}$ but is of importance. When grafting tissue of different immunological disparity, there is local cytokine production that may affect the stability and development of stem cells. ${ }^{93}$ It is predicted that rejection will occur with many different types of stem cells, especially ES and non-neural stem cells. It is therefore important to investigate this aspect of stem cell behavior.

\section{CONCLUSION}

Immune responses in the brain are complex, but cannot be ignored when it comes to repair strategies involving cellular transplants. The immune responses are regulated and depend on several factors that we have discussed in this chapter. Rejecting neural grafts produce and elicit cytokine responses that may contribute to functional effects observed in patients, and it is possible that subacute rejection may produce some of the abnormal movements seen after grafting in some patients with PD.

Despite the issues of immune-mediated rejection and the theoretical risk of infection with porcine endogenous retroviruses, xenogeneic neural tissues are an attractive source of material for use in brain repair surgery. Development of transgenic pigs to reduce antigenicity while limiting the risk of infection with PERVs may allow the exploitation of the unique properties of a xenografting situation discussed above to more completely reverse CNS circuit degeneration.

The immunology of grafted stem cells has not been extensively studied, but is of importance. Indeed, until we have a better understanding of the immune mechanisms mediating neural graft rejection, the use of all cell therapies for neurological disorders will be fraught with difficulties.

Acknowledgments: R.A.B.'s work was supported by the Parkinson's Disease Society and Wellcome trust. This work was partially supported by the Medical Research Council and Imutran Ltd. (a Novartis Pharma AG Company). H.W.'s work was supported by the European Union-Biomed II program BMH4-CT-97-2596, "Development of a xenogeneic donor tissue for neural transplantation in neurodegenerative disorders," the Swedish Medical Research Council Grant 12XC-122436, the Medical Faculty at Lund University, the Segerfalk Foundation, the Kock Foundation, the Wiberg Foundation, the Bergwall Foundation, the Crafoord Foundation, the Neurologically Handicapped Organization, and the Swedish Society for Medical Research.

\section{REFERENCES}

1. Billingham RW, Boswell T. Studies on the problem of corneal honografts. Proc R Soc Lond B Biol Sci 141:392-406, 1953.

2. Barker CF, Billingham RE. Immunologically privileged sites. $A d v$ Immunol 25:1-54, 1977.

3. Brabb T, von Dassow P, Ordonez N, Schnabel B, Duke B, Goverman J. In situ tolerance within the central nervous system as a mechanism for preventing autoimmunity. J Exp Med 192:871$880,2000$.

4. Widner H, Brundin P. Immunological aspects of grafting in the mammalian central nervous system. A speculative synthesis. Brain Res Rev 13:287-324, 1988.

5. Hickey WH. Basic principles of immunological surveillance of the normal central nervous system. Glia 36:118-124, 2001.

6. Auchincloss H, Sultan H. Antigen processing and presentation in transplantation. Curr Opin Immunol 8:681-687, 1996.

7. Hong S, Scherer DC, Singh N, Mendiratta SK, Serizawa I, Koezuka Y, Van Kaer L. Lipid antigen presentation in the immune system: lessons learned from CD1d knockout mice. Immunol Rev 169:31-44, 1999.

8. Mason DW, Charlton HM, Jones AJ, Lavy CB, Puklavec M, Simmonds SJ. The fate of allogeneic and xenogeneic neuronal tissue transplanted into the third ventricle of the rodents. Neuroscience 19:685-694, 1986.

9. Pakzaban P, Isacson O. Neuronal xenotransplantation: reconstruction of neuronal circuitry across species barriers. Neuroscience 62:989-1001, 1994.

10. Brevig T, Holgersson J, Widner H. Xenotransplantation for CNS repair: immunological barriers and strategies to overcome them. Trends Neurosci 23:337-344, 2000.

11. Cascalho M, Platt JL. The immunological barrier to xenotransplantation. Immunity 14:437-446, 2001.

12. Galili U. Interaction of the natural anti-Gal antibody with $\alpha$-galactosyl epitopes: a major obstacle for xenotransplantation in humans. Immunol Today 14:480-482, 1993.

13. Brundin P, Widner H, Nilsson OG, Strecker RE, Björklund A. Intracerebral xenografts of dopamine neurons: the role of immunosuppression and the blood-brain barrier. Exp Brain Res 75:195207, 1989.

14. Barker-Cairns BJ, Sloan DJ, Broadwell RD, Puklavec M, Charlton HM. Contribution of donor and host blood vessels in CNS allografts. Exp Neurol 142:36-46, 1996.

15. Steward PA, Clements CA, Wiley MJ. Revascularization of skin transplanted into the brain: source of the graft endothelium. Microvasc Res 28:113-124, 1984.

16. Hart DNJ, Fabre WJ. Demonstration and characterization of Iapositive dendritic cells in the interstitial connective tissues of rat heart and other tissue, but not brain. J Exp Med 153:347-361, 1981. 
17. Lowenstein PR. Immunology of viral-vector-mediated gene transfer into the brain: an evolutionary and developmental perspective. Trends Immunol 23:23-30, 2002.

18. Perry VH, Hume DA, Gordon S. Immunohistochemical localisation of macrophages and microglia in the adult and developing mouse brain. Neuroscience 15:313-326, 1985.

19. Graeber MB, Streit WJ. Perivascular microglia defined. Trends Neurosci 13:366-370, 1990.

20. Hickey WF, Kimura H. Perivascular microglial cells of the CNS are bone-marrow derived and present antigen in vivo. Science 239:290-292, 1988.

21. Banchereau J, Steinman RM. Dendritic cells and the control of immunity. Nature 392:245-252, 1998.

22. Santambrogio L, Belyanskaya SL, Fischer FR, Cipriani B, Brosnan CF, Ricciardi-Castagnoli P, Stern LJ, Strominger JL, Riese R. Developmental plasticity of CNS microglia. Proc Natl Acad Sci USA 98:6295-6300, 2001.

23. Czapiga M, Colton CA. Function of microglia in organotypic slice cultures. J Neurosci Res 56:644-651, 1999.

24. Prineas JW. Multiple sclerosis: presence of lymphatic capillaries and lymphoid tissue in the brain and spinal cord. Science 203: 1123-1125, 1979.

25. Fischer HG, Bielinsky AK. Antigen presentation function of brainderived dendriform cells depends on astrocyte help. Int Immunol 11:1265-1274, 1999.

26. Gould DS, Auchincloss H Jr. Direct and indirect recognition: the role of MHC antigens in graft rejection. Immunol Today 20:77-82, 1999.

27. Waldmann H, Cobbold S. Regulating the immune response to transplants. A role for CD4+ regulatory cells? Immunity 14:399406, 2001.

28. Maloy KJ, Poiwre F. Regulatory T cells in the control of immune pathology. Nat Immunol 2:816-822, 2001.

29. Dean M, Rzhetsky A, Allikmets R. The human ATP-binding cassette (ABC) transporter superfamily. Genome Res 11:1156-1166, 2001.

30. Baron JL, Madri JA, Ruddle NH, Hashim G, Janeway CA. Surface expression of a4 integrin by CD4 T cells is required for their entry into the brain parenchyma. J Exp Med 177:57-68, 1993.

31. Merrill JE, Murphy SP. Inflammatory events at the blood brain barrier: regulation of adhesion molecules, cytokines, and chemokines by reactive nitrogen and oxygen species. Brain Behav Immun 11:245-263, 1997.

32. Streilein WJ. Tissue barrier, immunosuppressive microenvironments, and privileged sites: the eye's point of view. Regul Immunol 5:253-268, 1993.

33. Wang T, Donahue PK, Zervos AS. Specific interaction of type I receptors of the TGF- $\beta$ family with the immunophilin FKBR-12. Science 265:674-676, 1994.

34. Bechmann I, Mor G, Nilsen J, Eliza M, Nitsch R, Naftolin F. FasL (CD95L, Apo1L) is expressed in the normal rat and human brain: evidence for the existence of an immunological brain barrier. Glia 27:62-74, 1999.

35. Widner H. Immunological issues in rodent and primate transplants (allografts). In: Cell transplantation for neurological disorders. Toward reconstruction of the human central nervous system (Freeman T, Widner H, eds), pp 171-188. Totowa, NY: Humana Press, 1998.

36. Pedersen EB, Poulsen FR, Zimmer J, Finsen B. Prevention of mouse-rat brain xenograft rejection by a combination therapy of cyclosporin A, prednisolone and azathioprine. Exp Brain Res 106: 181-186, 1995.

37. Mirza B, Hadberg H, Thomsen $\mathrm{P}$, Moos $\mathrm{T}$. The absence of reactive astrocytosis is indicative of a unique inflammatory process in Parkinson's disease. Neuroscience 95:425-432, 1999.

38. Okura Y, Tanaka R, Ono K, Yoshida S, Tanuma N, Matsumoto Y. Treatment of rat hemiparkinson model with xenogeneic neural transplantation: tolerance induction by anti-T-cell antibodies. J Neurosci Res 48:385-396, 1997.

39. Wood MJ, Sloan DJ, Wood KJ, Charlton HM. Indefinite survival of neural xenografts induced with anti-CD4 monoclonal antibodies. Neuroscience 70:775-789, 1996.

40. Larsson LC, Corbascio M, Widner H, Pearson TC, Larsen CP, Ekberg H. Simultaneous inhibition of B7 and LFA-1 signaling prevents rejection of discordant neural xenografts in mice lacking CD40L. Xenotransplantation 9:68-76, 2002.

41. Larsson LC, Corbascio M, Pearson TC, Larsen CP, Ekberg H, Widner H. Induction of operational tolerance to discordant dopaminergic porcine xenografts. Transplantation 75:1448-1454, 2003.

42. Widner H, Brundin P, Björklund A, Möller E. Survival and immunogenicity of dissociated allogeneic fetal neural dopamine-rich grafts when implanted into the brains of adult mice. Exp Brain Res 76:187-197, 1989.

43. Widner H, Brundin P. Sequential intracerebral transplantation of allogeneic and syngeneic fetal dopamine-rich neuronal tissue in adult rats: will the first graft be rejected? Cell Transplant 2:307317, 1993.

44. Duan W-M, Brundin P, Björklund A, Widner H. Sequential intracerebral transplantation of allogeneic and syngeneic fetal dopamine-rich neuronal tissue in adult rats: will the second graft be rejected? Neuroscience 57:261-274, 1994.

45. Duan W-M, Cameron RM, Brundin P, Widner H. Rat intrastriatal neural allografts challenged with skin allografts at different timepoints. Exp Neurol 148:334-347, 1997.

46. Duan W-M, Widner H, Cameron RM, Brundin P. Quinolinic acidinduced inflammation in the striatum does not impair the survival of neural allografts in the rat. Eur J Neurosci 10:2595-2606, 1998.

47. Schwarz SC, Kupsch AR, Banati R, Oertel WH. Cellular immune reactions in brain transplantation: effects of graft pooling and immunosuppression in the 6-hydroxydopamine rat model of Parkinson's disease. Glia 17:103-120, 1996.

48. Wood MJ, Sloan DJ, Dallman MJ, Charlton HM. Specific tolerance to neural allografts induced with an antibody to the interleukin 2 receptor. J Exp Med 177:597-603, 1993.

49. Bachoud-Levi AC, Hantraye P, Peschanski M. Fetal neural grafts for Huntington's disease: a prospective view. Mov Disord 17:439_ 444, 2002.

50. Barker RA. Repairing the brain in Parkinson's disease: where next? Mov Disord 17:233-241, 2002.

51. Björklund A, Lindvall O. Cell replacement therapies for central nervous system disorders. Nat Neurosci 3:537-544, 2000.

52. Lindvall O, Hagell P. Clinical observations after neural transplantation in Parkinson's disease. Prog Brain Res 127:299-320, 2000.

53. Olanow CW, Goetz CG, Kordower JH, Stoessl AJ, Sossi V, Brin MF, Shannon KM, Nauert GM, Perl DP, Godbold J, Freeman TB. A double-blind controlled trial of bilateral fetal nigral transplantation in Parkinson's disease. Ann Neurol 54:403-414, 2003.

54. Freed CR, Greene PE, Breeze RE, Tsai WY, DuMouchel W, Kao R, Dillon S, Winfield H, Culver S, Trojanowski JQ, Eidelberg D, Fahn S. Transplantation of embryonic dopamine neurons for severe Parkinson's disease. N Engl J Med 344:710-719, 2001.

55. Spencer DD, Robbins RJ, Naftolin F, Marek KL, Vollmer T, Leranth C, Roth RH, Price LH, Gjedde A, Bunney BS, Sass KJ, Elsworth JD, Kier EL, Makuch R, Hoffer PB, Redmond DE. Unilateral transplantation of human fetal mesencephalic tissue into the caudate nucleus of patients with Parkinson's disease. $N$ Engl $J$ Med 327:1541-1548, 1992.

56. Sauer H, Frodl EM, Kupsch A, ten Bruggencate G, Oertel WH. Cryopreservation, survival and function of intrastriatal fetal mesencephalic grafts in a rat model of Parkinson's disease. Exp Brain Res 90:54-62, 1992.

57. Hagell P, Brundin P. Cell survival and clinical outcome following intrastriatal transplantation in Parkinson disease. J Neuropathol Exp Neurol 60:741-752, 2001.

58. Kordower JH, Freeman TB, Snow BJ, Vingerhoets FJG, Mufson EJ, Sanberg PR, Hauser RA, Smith DA, Nauert GM, Perl DP, Olanow CW. Neuropathological evidence of graft survival and striatal reinnervation after the transplantation of fetal mesencephalic tissue in a patient with Parkinson's disease. $N$ Engl J Med 332:1118-1124, 1995.

59. Kordower JH, Styren S, Clarke M, DeKosky ST, Olanow CW, Freeman TB. Fetal grafting for Parkinson's disease: expression of immune markers in two patients with functional fetal nigral implants. Cell Transplant 6:213-219, 1997.

60. Pedersen EB, Widner H. Xenotransplantation. Prog Brain Res 127:157-188, 2000. 
61. Barker RA, Ratcliffe E, McLaughlin M, Richards A, Dunnett SB. A role for complement in the rejection of porcine ventral mesencephalic xenografts in a rat model of Parkinson's disease. $J$ Neurosci 20:3415-3424, 2000.

62. Larsson LC, Czech KA, Widner H, Korsgren O. Discordant neural tissue xenografts survive longer in immunoglobulin deficient mice. Transplantation 68:1153-1160, 1999.

63. Hurelbrink CB, Armstrong RJ, Dunnett SB, Rosser AE, Barker RA. Neural cells from primary human striatal xenografts migrate extensively in the adult rat CNS. Eur J Neurosci 15:1255-1266, 2002.

64. Brevig T, Pedersen EB, Kristensen T, Zimmer J. Proliferative response of human $\mathrm{T}$ lymphocytes to porcine fetal brain cells. Cell Transplant 6:571-577, 1997.

65. Wennberg L, Czech KA, Larsson L, Bennett W, Song Z, Widner H. Effects of immunosuppressive treatment on host responses and survival of porcine neural xenografts in rats. Transplantation 71 : 1797-1806, 2001.

66. Galpern WR, Burns LH, Deacon TW, Dinsmore J, Isacson O. Xenotransplantation of porcine ventral mesencephalon in a rat model of Parkinson's disease: functional recovery and graft morphology. Exp Neurol 140:1-13, 1996.

67. Larsson LC, Czech KA, Brundin P, Widner H. Intrastriatal ventral mesencephalic xenografts of porcine tissue in rats: immune response and functional effects. Cell Transplant 9:261-272, 2000.

68. Sumitran S, Liu J, Czech KA, Christensson B, Widner H, Holgersson J. Human natural antibodies cytotoxic to pig embryonic brain cells recognize novel non-Gal $\alpha 1,3 \mathrm{Gal}$-based xenoantigens. Exp Neurol 159:347-361, 1999.

69. Cicchetti F, Fodor W, Deacon TW, van Horne C, Rollins S, Burton $\mathrm{W}$, Costantini LC, Isacson O. Immune parameters relevant to neural xenograft survival in the primate brain. Xenotransplantation 10:41-49, 2003

70. Harrower TP, Richards A, Cruz G, Copeman L, Dunnett SB, Barker RA. Complement regulatory proteins are expressed at low levels in embryonic human, wild type and transgenic porcine neural tissue. Xenotransplantation 11:60-71, 2004.

71. Schumacher JM, Ellias SA, Palmer EP, Kott HS, Dinsmore J, Dempsey PK, Fischman AJ, Thomas C, Feldman RG, Kassissieh S, Raineri R, Manhart C, Penney D, Fink JS, Isacson O. Transplantation of embryonic porcine mesencephalic tissue in patients with PD. Neurology 54:1042-1050, 2000.

72. Deacon T, Schumacher J, Dinsmore J, Thomas C, Palmer P, Kott S, Edge A, Penney D, Kassissieh S, Dempsey P, Isacson O. Histological evidence of fetal pig neural cell survival after transplantation into a patient with Parkinson's disease. Nat Med 3:350-353, 1997.

73. Fink JS, Schumacher JM, Ellis SL, Plamer EP, Saint-Hilare M. Porcine xenografts in Parkinson's and Huntington's disease patients: preliminary results. Cell Transplant 9:273-278, 2000.

74. Weiss RA. Xenografts and retroviruses. Science 285:1221-1222, 1999.

75. Paradis K, Langford G, Long Z, Heneine W, Sandstrom P, Switzer WM, Chapman LE, Lockey C, Onions D, Otto E. Search for cross-species transmission of porcine endogenous retrovirus in patients treated with living pig tissue. The XEN 111 Study Group. Science 285:1236-1241, 1999.

76. Dinsmore J, Mnahart C, Raineri R. No evidence for infection of human cells with porcine endogenous retrovirus (PERV) after exposure to porcine fetal neuronal cells. Transplantation 70:13821389,2000

77. Brown VJ, Dunnett SB. Comparison of adrenal and fetal nigral grafts on drug-induced rotation in rats with 6-OHDA lesions. Exp Brain Res 78:214-218, 1989.
78. Dunnett SB, Björklund A. Prospects for new restorative and neuroprotective treatments in Parkinson's disease. Nature 399:A32A39, 1999.

79. Horellou P, Vigne E, Castel MN, Barneoud P, Colin P, Perricaudet M, Delaere P, Mallet J. Direct intracerebral gene transfer of an adenoviral vector expressing tyrosine hydroxylase in a rat model of Parkinson's disease. NeuroReport 6:49-53, 1994.

80. Thomas CE, Birkett D, Anozie I, Castro MG, Lowenstein PR. Acute direct adenoviral vector cytotoxicity and chronic, but not acute, inflammatory responses correlate with decreased vectormediated transgene expression in the brain. Mol Ther 1:36-46, 2001.

81. Byrnes AP, Wood MJ, Charlton HM. Role of T cells in inflammation caused by adenovirus vectors in the brain. Gene Ther 3:644-651, 1996.

82. Gray DW. An overview of the immune system with specific reference to membrane encapsulation and islet transplantation. Ann NY Acad Sci 944:226-239, 2001.

83. Temple S. Stem cell plasticity-building the brain of our dreams. Nat Rev Neurosci 2:513-520, 2001.

84. Lanza RP, Chung HY, Yoo JJ, Wettstein PJ, Blackwell C, Borson N, Hofmeister E, Schuch G, Soker S, Moraes CT, West MD, Atala A. Generation of histocompatible tissues using nuclear transplantation. Nat Biotechnol 20:689-696, 2002.

85. Björklund L, Sanchez-Pernaute R, Chung S, Andersson T, Yin Ching Chen I, McNaught K, Brownell A-L, Jenkins BG, Wahlstedt C, Kim K-S, Isacson O. Embryonic stem cells develop into functional dopaminergic neurons after transplantation in a Parkinson rat model. Proc Natl Acad Sci USA 99:2344-2349, 2002.

86. Armstrong RJ, Hurelbrink CB, Tyers P, Ratcliffe EL, Richards A, Dunnett SB, Rosser AE, Barker RA. The potential for circuit reconstruction by expanded neural precursor cells explored through porcine xenografts in a rat model of Parkinson's disease. Exp Neurol 175:98-111, 2002.

87. Fricker RA, Carpenter MK, Winkler C, Greco C, Gates MA, Björklund A. Site-specific migration and neuronal differentiation of human neural progenitor cells after transplantation in the adult rat brain. $J$ Neurosci 19:5990-6005, 1999.

88. Rosser AE, Tyers P, Dunnett SB. The morphological development of neurons derived from EGF- and FGF-2-driven human CNS precursors depends on their site of integration in the neonatal rat brain. Eur J Neurosci 12:2405-2413, 2000.

89. Olsson M, Bentlage C, Wictorin K, Campbell K, Björklund A. Extensive migration and target innervation by striatal precursors after grafting into the neonatal striatum. Neuroscience 79:57-78, 1997.

90. Blixt Wojciechowski A, Englund U, Lundberg C, Wictorin K, Warfinge K. Subretinal transplantation of brain-derived precursor cells to young RCS rats promotes photoreceptor cell survival. Exp Eye Res 75:23-37, 2002.

91. Blixt Wojciechowski A, Englund U, Lundberg C, Warfinge K. The brain derived precursor cell line RN33B and its response to different immunosuppression after subretinal transplantation to the adult normal rat. Exp Eye Res (in press).

92. Armstrong RJ, Harrower TP, Hurelbrink CB, McLaughin M, Ratcliffe EL, Tyers P, Richards A, Dunnett SB, Rosser AE, Barker RA. Porcine neural xenografts in the immunocompetent rat: immune response following grafting of expanded neural precursor cells. Neuroscience 106:201-216, 2001.

93. Mirza B, Krook H, Andersson P, Larsson L, Korsgren O, Widner $H$. Intracerebral cytokine profiles in adult rats grafted with neural tissue of different immunological disparity. Brain Res Bull 63: 105-118, 2004. 